\title{
Plate-Clamp Assisted Reduction of the Posterior Column of a Displaced Acetabular Fracture- Technical Note
}

\begin{abstract}
Varatharaj Mounasamy ${ }^{1 *}$, Kendall Anigian², Kshitij Manchanda ${ }^{3}$, Sushruthi Vartharaj ${ }^{4}, J^{2}$ Janananda Satpathy ${ }^{5}$ and Sambandam Senthil ${ }^{6}$
\end{abstract}

${ }^{1}$ Professor of Orthopedics at UTSW, Orthopedic Chief at Dallas VAMC, USA

${ }^{2}$ Orthopedic Resident,UT Southwestern,Dallas,USA

${ }^{3}$ Orthopedic surgeon, Miami Orthopaedics and Sports Medicine Institute, USA

${ }^{4}$ Medical student, Burrell College of Osteopathic Medicine, Las Cruces, New Mexico

${ }^{5}$ Department of Orthopaedic Surgery, Virginia Commonwealth University Health, USA

${ }^{6}$ Department of Orthopedics, VA Medical center, USA

Submission: August 23, 2020; Published: September 02, 2020

*Corresponding author: Vartharaj Mounasamy MD, Professor of Orthopedics at UTSW, Orthopedic Chief at Dallas VAMC, Dallas, Texas, USA

Abstract

We describe a novel method of plate-clamp assisted reduction of the displaced posterior column component of a transverse acetabular fracture. This technique allows fixation of the fracture with the fracture reduced with the plate applied simultaneously during reduction.

Keywords: Posterior column; Clamp

\section{Introduction}

Acetabular fractures usually occur after high energy trauma and significant percent of these fractures need open reduction and internal fixation. Surgical approach is determined by fracture obliquity and the column which is maximally displaced [1]. Kocher-Langenbeck approach is chosen if posterior column component is maximally displaced or if an associated transverse and posterior wall fracture pattern is present and in addition to few other situations like a segmental posterior column fracture.

Kocher- Langenbeck can be performed in lateral or prone position. Positioning of the patient is dependent on surgeon familiarity, experience and his/her fellowship training. Patient's associated injuries like rami fractures/bladder injury and associated cervical spine injury also play an important role in positioning. Prone positioning helps with ease in reduction of the fracture. Trochanteric flip osteotomy in prone position is difficult if needed to be performed for an associated femoral head fracture [2] (Table 1). Inaccurate reduction of acetabular fracture has been reported in lateral position [3]. Anterior column can be fixed with a separate screw or a second plate in the posterior column can aid in stability [4].

\section{Surgical Technique}

We describe a plate-clamp assisted reduction technique of the displaced posterior column component of the transverse fracture done through a Kocher-Langenbeck approach. Clamp assisted reduction of the fracture with Jung luth /Farabeuf clamp is well known among acetabular surgeons and is commonly used (Figure 1). After reduction with a clamp, in some cases (Particularly with an associated Posterior wall fracture) there is not enough space for a plate to be placed. This will require use of a Kirschner wire to hold the reduction achieved by the clamp and remove the clamp which could lead to loss of reduction. This is also further made difficult in the lateral position due the weight of the limb causing displacement /medialization of the distal fragment. Hence, we describe this new technique wherein the fracture is reduced with the plate with clamp in-situ.

\section{We describe a technique}

Step 1. Drill a hole and place one $3.5 \mathrm{~mm}$ screw (6 mm longer than measured length with leaving $4 \mathrm{~mm}$ proud) proximal to the fracture. 


\section{Orthopedics and Rheumatology Open Access Journal (OROAJ)}

Step 2. Drill a hole and place one $3.5 \mathrm{~mm}$ screw (8 $\mathrm{mm}$ longer than measured length with leaving $4 \mathrm{~mm}$ proud) through the $5^{\text {th }}$ hole of low profile under -contoured six-hole pelvis reconstruction plate distal to the fracture (Figure 2).

Step 3. Anatomically reduce the fracture-using a Jung luth clamp with one prong in screw described in step 1 and one prong over the plate/screw described in step 2. Confirm reduction palpating the retro-acetabular surface and using fluoroscopy
(Figure 3).

Step 4. Complete screw placement in hole 1,2, 3 and 6 (Figure $4)$.

Step 5. Remove clamp, check reduction and place screw of appropriate length in hole 5 of six-hole plate (Figure 5). Step 6. Remove screw placed in step 1

Step 7. Confirm reduction palpating the retro-acetabular surface and using fluoroscopy.

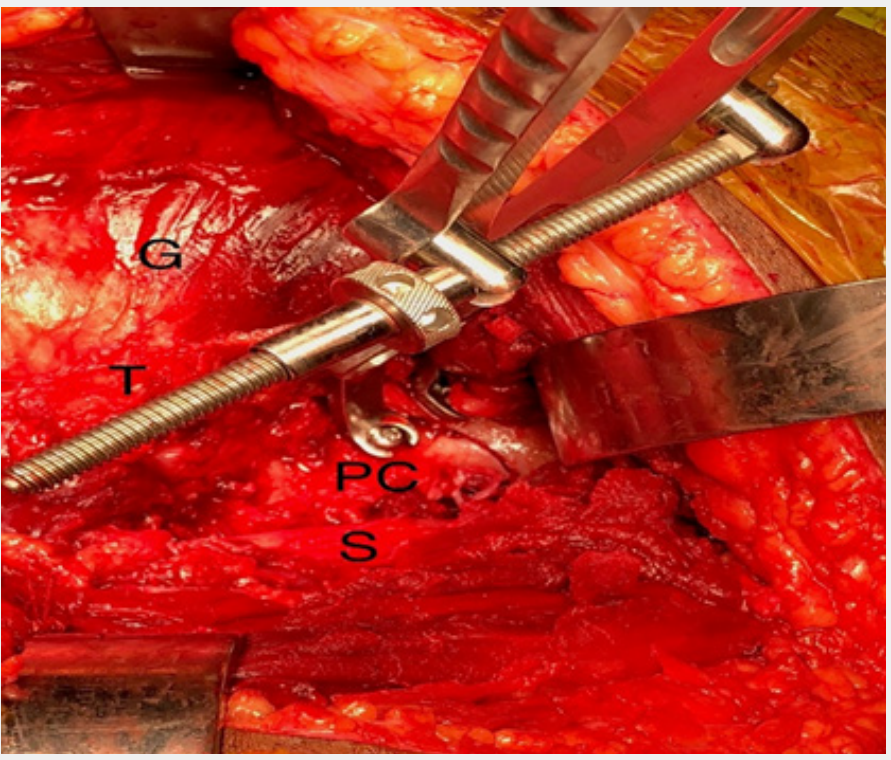

Figure 1: Posterior column fracture reduced over screws and clamp leading to interference with plate fixation. T- Trochanter, G-Gluteus medius, S- Sciatic nerve and PC- posterior column.
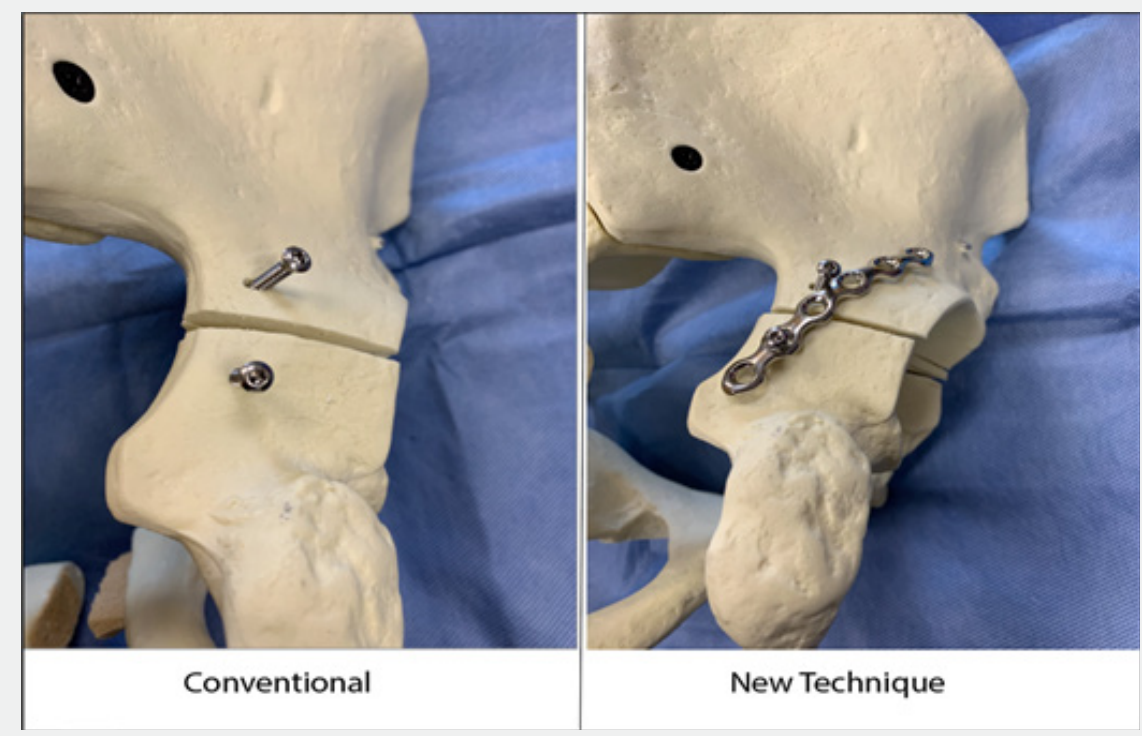

Figure 2: Placement of screw in the conventional technique and the current technique with one screw through the plate and other outside the plate with fracture unreduced. 


\section{Orthopedics and Rheumatology Open Access Journal (OROAJ)}

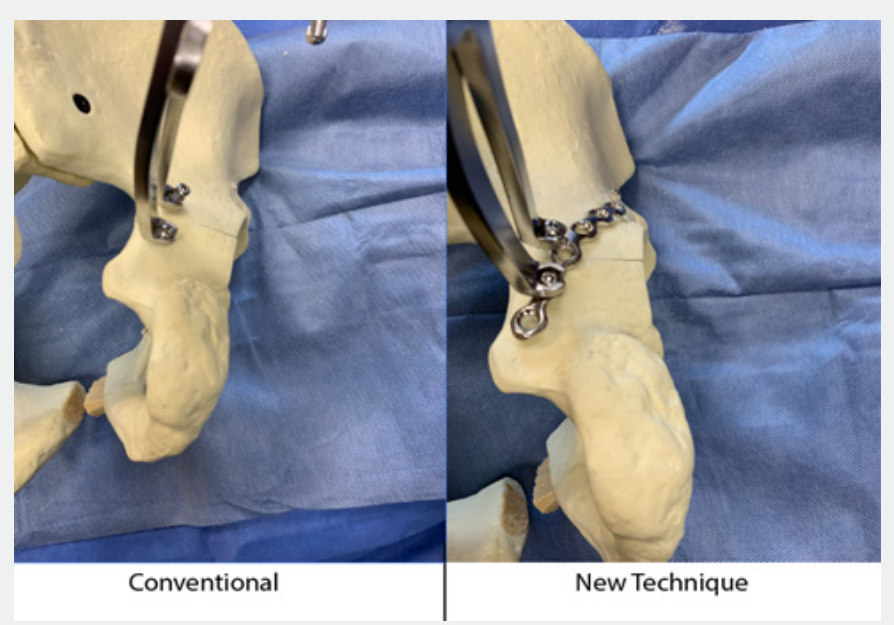

Figure 3: Placement of the Clamp over the screw achieving compression in the conventional technique and current technique.

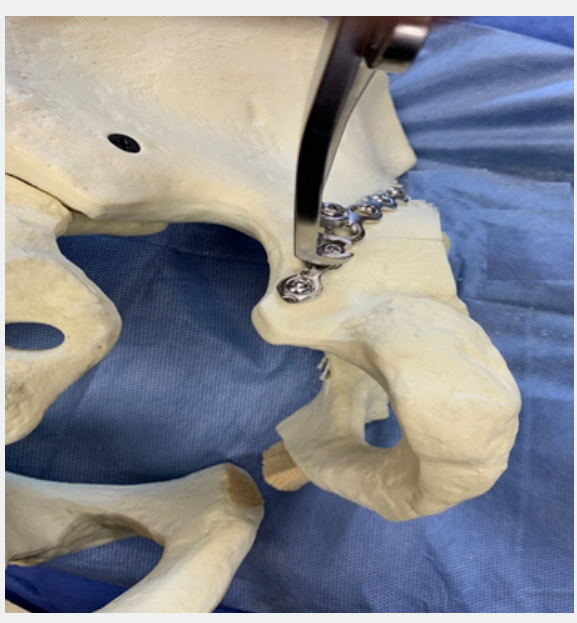

Figure 4: Placement of all the screws maintaining reduction with the clamp.

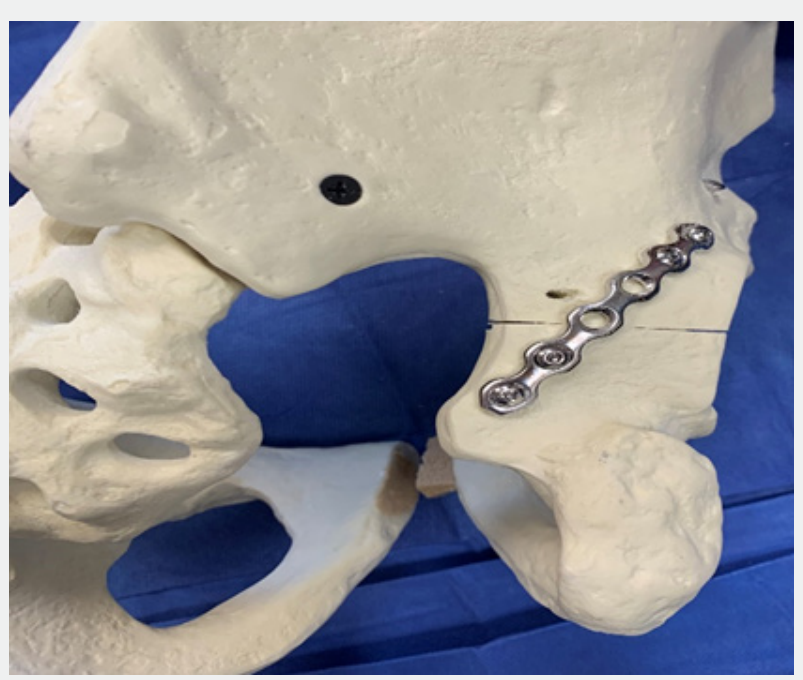

Figure 5: Removal of the clamp and outside screw with tightening of the final screw in the plate and final completed appearance of the fracture plate construct. 
Table 1: Kocher-Langenbeck approach.

\begin{tabular}{|c|c|}
\hline Lateral Position & Prone position \\
\hline Advantages & Advantages \\
\hline Soft tissues and muscle fall away from surgical field & Eliminates gravity as a potential deforming force \\
\hline Ease of Troch Flip Osteotomy & Easier palpation of retroacetabular surface and clamp application \\
\hline Preferred in patients with Bladder injury/rami fractures & $\begin{array}{c}\text { Ease to place an anterior column screw } \\
\text { Dciatic nerve injury }\end{array}$ \\
\hline Disadvantages & $\begin{array}{c}\text { Disadvantages } \\
\text { Surgeon Familiarity with approach }\end{array}$ \\
\hline $\begin{array}{c}\text { Difficulty in view of gravity causing Internal rotation and medialization } \\
\text { of distal fragment due to the weight of the lower extremity }\end{array}$ & \begin{tabular}{c} 
Soft tissues falling in field of Surgery \\
\hline Difficulty to place an anterior column screw
\end{tabular} \\
\hline
\end{tabular}

\section{Conclusion}

The plate-clamp assisted reduction technique (Mounasamy Technique) of the displaced posterior column component which we describe allows the reduction to be stabilized with the plate immediately before removal of the clamp.

\section{Disclosure Statement}

None of the authors have anything to disclose. None of the authors have any conflict of interest.

\section{References}

1. Letournel E, Judet R (1993) Fractures of the acetabulum. $2^{\text {nd }}$ edn, Springer, Verlag, Berlin, Germany.
2. Cutrera NJ, Pinkas D, Toro JB (2015) Surgical approaches to the acetabulum and modifications in Technique. J Am Acad Orthop Surgeons 23(10): 592-603

3. Collinge C, Archdeacon M, Sagi H (2011) Quality of radiographic reduction and perioperative complications for transverse acetabular fractures treated with a Kocher-Langenbeck approach: Prone versus lateral position. J Orthop Trauma 25(9): 538-542.

4. Fahmy M, Karim MA, Khaled SA, Ahmed Hazem Abdelazeem, Walid A Elnahal, et al. (2018) Single versus double column fixation in transverse fractures of the acetabulum: A randomised controlled trial. Injury Intl J Care Injured 49(7): 1291-1296.

\section{Your next submission with Juniper Publishers will reach you the below assets}

- Quality Editorial service

- Swift Peer Review

- Reprints availability

- E-prints Service

- Manuscript Podcast for convenient understanding

- Global attainment for your research

- Manuscript accessibility in different formats ( Pdf, E-pub, Full Text, Audio)

- Unceasing customer service

Track the below URL for one-step submission https://juniperpublishers.com/online-submission.php 